\title{
Maintenance requirement and deposition efficiency of lysine in pigs
}

\author{
Marcos Speroni Ceron ${ }^{(1)}$, Vladimir de Oliveira(1), Paulo Alberto Lovatto ${ }^{(2)}$ and Marcos Martinez do Vale(1)
}

(1)Universidade Federal de Santa Maria, Departamento de Zootecnia, Avenida Roraima, o⒈000, Cidade Universitária, Camobi, CEP $97105-900$ Santa Maria, RS, Brazil. E-mail: marcossperoni@gmail.com, vladimir.oliveira@ufsm.br, mmdovale@hotmail.com ${ }^{(2)}$ In memoriam.

\begin{abstract}
The objective of this work was to determine the maintenance requirement and the deposition efficiency of lysine in growing pigs. It was used the incomplete changeover experimental design, with replicates over time. Twelve castrated pigs with average body weight (BW) of $52 \pm 2 \mathrm{~kg}$ were kept in metabolism crates with a controlled temperature of $22^{\circ} \mathrm{C}$. The diets were formulated to supply $30,50,60$, and $70 \%$ of the expected requirements of standardized lysine, and provided at 2.6 times the energy requirements for maintenance. The trial lasted 24 days and was divided into two periods of 12 days: seven days for animal adaptation to the diet and five days for sample collection. The increasing content of lysine in the diet did not affect dry matter intake of the pigs. The amount of nitrogen excreted was $47 \%$ of the nitrogen intake, of which $35 \%$ was excreted through feces and $65 \%$ through urine. The estimated endogenous losses of lysine were $36.4 \mathrm{mg} \mathrm{kg}^{-1} \mathrm{BW}^{0.75}$. The maintenance requirement of lysine for pigs weighing around $50 \mathrm{~kg}$ is $40.4 \mathrm{mg} \mathrm{kg}^{-1} \mathrm{BW}^{0.75}$, and the deposition efficiency of lysine is $90 \%$.
\end{abstract}

Index terms: amino acid requirement, nitrogen, pig production, swine nutrition.

\section{Exigência de manutenção e eficiência de deposição de lisina em suínos}

Resumo - O objetivo deste trabalho foi determinar a exigência de manutenção e a eficiência de deposição de lisina em suínos em crescimento. Utilizou-se o delineamento experimental permutável, com repetições ao longo do tempo. Doze suínos castrados com peso vivo (PV) médio de $52 \pm 2 \mathrm{~kg}$ foram alojados em gaiolas metabólicas, com temperatura controlada de $22^{\circ} \mathrm{C}$. As dietas foram formuladas para fornecer $30,50,60 \mathrm{e}$ $70 \%$ das exigências esperadas de lisina estandardizada e fornecidas para atender 2,6 vezes a exigência de energia para manutenção. $\mathrm{O}$ experimento teve duração de 24 dias e foi dividido em dois períodos de 12 dias: sete para adaptação dos animais à dieta e cinco para coleta de amostras. $\mathrm{O}$ teor crescente de lisina na dieta não influenciou a ingestão de matéria seca pelos suínos. A quantidade de nitrogênio excretado foi de $47 \%$ do ingerido, dos quais $35 \%$ foram excretados pelas fezes e $65 \%$ pela urina. As perdas endógenas de lisina estimadas foram de $36,4 \mathrm{mg} \mathrm{kg}^{-1} \mathrm{PV}^{0,75}$. A exigência de manutenção de lisina em suínos com aproximadamente $50 \mathrm{~kg}$ é de $40,4 \mathrm{mg} \mathrm{kg}^{-1} \mathrm{PV}^{0,75}$, e a eficiência de deposição de lisina é de $90 \%$.

Termos para indexação: exigência de aminoácidos, nitrogênio, suinocultura, nutrição de suínos.

\section{Introduction}

Understanding the nutritional requirements of pigs is essential to develop dietary strategies to maximize economic profit and minimize nutrient excretion.

The factorial method used to determine amino acid requirements divides the total demands into two factors: maintenance and protein growth (Sakomura \& Rostagno, 2007; Pomar et al., 2009). Amino acid maintenance requirements are based on the assumption that there is a constant metabolic activity. Therefore, nitrogen products need to be restored in order to prevent a negative nitrogen balance (Moughan, 2003). The main biological events that determine the maintenance requirements are: endogenous amino acid losses, inefficiency of the protein synthesis process, hair loss and desquamation (Moughan, 2003).

Protein growth or protein deposition capacity is influenced by factors such as genetics, gender, age, and sanitary status of the animal. Knowledge about the protein deposition curve is vital when the intention is to use the factorial method to determine the maintenance requirements. Information on how the absorbed amino acids are efficiently used to form body proteins are also necessary. The marginal efficiency of amino acid utilization may be estimated by the angular coefficient of the relationship between the ingested and retained amino acids. A diet with different levels of limiting 
amino acids must be provided, which, in turn, must be below the requirement for maximum deposition and the only limiting factor for protein deposition.

The appropriate estimate of the efficiency of amino acid utilization is essential for the prediction of body protein deposition by mechanistic models of growth simulation (Wecke, 2010). The values of lysine deposition efficiency found by Libao-Mercado et al. (2006) and Heger et al. (2008) show significant variations, possibly due to the methodological differences between the experiments and the premises assumed in the calculations.

Several studies were conducted to determine total requirements (maintenance and deposition) of lysine for growing pigs (Heger et al., 2008; Van Milgen et al., 2008; Ringel \& Susenbeth, 2009). However, in Brazil, there are few studies on the maintenance requirements and efficiency of lysine for protein deposition, obtained separately.

The objective of this work was to determine the maintenance requirements and deposition efficiency of lysine in growing pigs.

\section{Materials and Methods}

The experimental protocol was reviewed and approved by Ethics Committee on Animal Experimentation from Universidade Federal de Santa Maria (opinion 005/2012), state of Rio Grande do Sul, Brazil.

The experiment was carried out with 12 castrated pigs, in the growing phase, with an average body weight (BW) of $52 \pm 2 \mathrm{~kg}$. The animals were kept in metabolism crates with a controlled temperature of $22^{\circ} \mathrm{C}$. The trial lasted 24 days and was divided into two periods: seven days for experimental diet adjustment and five days for sample collection.

The animals were distributed in a changeover design (Gill \& Magee, 1976) in four experimental diets, totaling six replicates per treatment, and the animal was considered as the experimental unit.

The experimental diets were prepared following the concept of ideal protein in order to meet the 30,50 , 60 , and $70 \%$ of the recommended lysine nutritional requirements (National Research Council, 1998). The remaining amino acids were added to the diets to obtain the proportion of, at least, $15 \%$ more in relation to their total requirements (Van Milgen et al., 2008).
The calculated and centesimal composition of the experimental diet are shown in Table 1.

The feed was provided at 2.6 times the metabolizable energy requirements for maintenance $\left(250 \mathrm{kcal} \mathrm{kg} \mathrm{kg}^{-1}\right.$ $\mathrm{BW}^{0.60}$ ), considering an adjustment on daily feed intake to achieve estimated daily average gain of $0.8 \mathrm{~kg}$. This high-energy consumption by the animals ensured that protein deposition was not affected by the concentration of energy in the diet (Moehn et al., 2013). The feed was distributed in four daily meals at 8:00, 11:00, 13:00, and 18:00 $\mathrm{h}$. The animals had free access to water.

In the experiment, the method of total collection of feces was used. The beginning and end of the collection

Table 1. Calculated and centesimal composition of diets of pigs fed with increasing levels of lysine.

\begin{tabular}{|c|c|c|c|c|}
\hline \multirow[t]{2}{*}{ Ingredients } & \multicolumn{4}{|c|}{ Level of lysine ( $\%$ of requirement) } \\
\hline & 30 & 50 & 60 & 70 \\
\hline Corn & 15.60 & 21.84 & 27.77 & 33.85 \\
\hline Soybean meal & 10.40 & 14.56 & 18.51 & 22.57 \\
\hline Starch & 59.90 & 48.96 & 38.55 & 27.85 \\
\hline Sugar & 10.00 & 10.00 & 10.00 & 10.00 \\
\hline Soybean oil & 1.00 & 1.50 & 2.00 & 2.50 \\
\hline DL-methionine & 0.050 & 0.070 & 0.090 & 0.115 \\
\hline L-threonine & 0.035 & 0.045 & 0.055 & 0.080 \\
\hline L-tryptophan & 0.015 & 0.020 & 0.025 & 0.035 \\
\hline Bicalcic phosphate & 1.5 & 1.5 & 1.5 & 1.5 \\
\hline Limestone & 0.9 & 0.9 & 0.9 & 0.9 \\
\hline Salt & 0.4 & 0.4 & 0.4 & 0.4 \\
\hline $\begin{array}{l}\text { Vitaminic and mineral } \\
\text { premix }\end{array}$ & 0.2 & 0.2 & 0.2 & 0.2 \\
\hline \multirow[t]{2}{*}{ Total } & 100.00 & 100.00 & 100.00 & 100.00 \\
\hline & \multicolumn{4}{|c|}{ Nutritional values calculated } \\
\hline Crude protein $(\%)$ & 6.50 & 8.80 & 11.00 & 13.30 \\
\hline $\mathrm{ME}\left(\mathrm{kcal} \mathrm{kg}^{-1}\right)$ & 3432 & 3424 & 3418 & 3412 \\
\hline Lysine $(\%)^{(1)}$ & $0.29^{(2)}(100)^{(3}$ & $0.41(100)$ & $0.52(100)$ & $0.63(100)$ \\
\hline Threonine (\%) & $0.23(79)$ & $0.32(78)$ & $0.41(79)$ & $0.51(81)$ \\
\hline Methionine (\%) & $0.13(45)$ & $0.19(46)$ & $0.24(46)$ & $0.30(48)$ \\
\hline Methionine+cysteine (\%) & $0.22(76)$ & $0.31(76)$ & $0.40(77)$ & $0.49(78)$ \\
\hline Tryptophan (\%) & $0.08(28)$ & $0.10(24)$ & $0.13(25)$ & $0.17(27)$ \\
\hline Isoleucine (\%) & $0.24(83)$ & $0.33(80)$ & $0.42(81)$ & $0.51(81)$ \\
\hline Valine $(\%)$ & $0.26(90)$ & $0.36(88)$ & $0.45(87)$ & $0.55(87)$ \\
\hline Leucine $(\%)$ & $0.46(159)$ & $0.64(156)$ & $0.81(156)$ & $0.99(157)$ \\
\hline Phenylalanine (\%) & $0.27(93)$ & $0.38(93)$ & $0.49(94)$ & $0.59(94)$ \\
\hline Phenylalanine+tyrosine (\%) & $0.46(159)$ & $0.65(159)$ & $0.83(160)$ & $1.01(160)$ \\
\hline Histidine $(\%)$ & $0.15(52)$ & $0.21(51)$ & $0.26(50)$ & $0.32(51)$ \\
\hline Arginine $(\%)$ & $0.38(131)$ & $0.54(132)$ & $0.68(131)$ & $0.83(132)$ \\
\hline
\end{tabular}

${ }^{(1)}$ Values expressed as standardized digestible amino acids. (2) Values obtained by multiplying the coefficient of standardized digestibility (Sauvant et al., 2004) of the analyzed amino acids in corn and soybean meal. ${ }^{\left({ }^{3}\right)}$ Values in parentheses represent the relation between lysine and the other amino acids of the experiment. ME, metabolizable energy. 
was determined by the appearance of marked feces (by adding $2 \%$ of $\mathrm{Fe}_{2} \mathrm{O}_{3}$ to the diets). The animal's feces were collected twice a day, packed into plastic bags, and kept in a freezer at $-10^{\circ} \mathrm{C}$. The urine excreted from the animals was drained into plastic containers, which contained $15 \mathrm{~mL}$ of $\mathrm{H}_{2} \mathrm{SO}_{4}$ and $15 \mathrm{~mL}$ of distilled water to prevent bacterial contamination and nitrogen volatilization.

The amino acid content of the corn and soybean meal used in the preparation of the diet was determined by acidic hydrolysis. The coefficients of ideal and standardized digestibility of soybean meal $(90 \%)$ and corn $(80 \%)$ were obtained from Sauvant et al. (2004) and implemented in the analyzed contents of lysine, in these ingredients. The partially dried matter of the ingredients, rations, and feces were determined in a forced air oven, at $60^{\circ} \mathrm{C}$, until reaching constant weight. Subsequently, these partially dried samples were placed in a forced air oven, at $105^{\circ} \mathrm{C}$, for 24 hours, to determine dry matter. The nitrogen of ingredients, rations, feces, and urine was determined according to Cuniff (1995).

The retained nitrogen was obtained by the difference between the ingested nitrogen and the total nitrogen eliminated through feces and urine (nitrogen balance). The protein deposition was determined by multiplying the retained nitrogen by 0.0625 , assuming that nitrogen constitutes $6.25 \%$ of the retained proteins (National Research Council, 1998). The amount of retained lysine was calculated by the difference between the ingested and deposited lysine, assuming that it constitutes $7.08 \%$ of body protein (Möhn et al., 2000). The maintenance requirement of lysine was obtained in the intersection point between the regression line and the abscissa axis, in which the $\mathrm{Y}$ and $\mathrm{X}$ axis represent the retained and ingested lysine, respectively.

The deposition efficiency of lysine was determined by the angular coefficient of the line originated by the regression of amino acid retention and intake (Libao-Mercado et al., 2006). The coefficient is the slope of the amino acid deposition efficiency, which is the proportion of ingested amino acid that was deposited in the animal body (Sakomura \& Rostagno, 2007).

The obtained data were subjected to analysis of variance, and the animal's effect, time, and treatment were used in the model. Subsequently, the linear regression procedure was performed by the Minitab program (McKenzie \& Goldman, 2010).

\section{Results and Discussion}

During the experimental period, the animals showed good health conditions and consumed all the provided feed.

The increasing levels of standardized ileal digestible lysine (SID lysine) did not affect dry matter intake, which was, on average, $97 \mathrm{~g} \mathrm{~kg}^{-1} \mathrm{BW}^{0.75}$ (Table 2). Increasing contents of SID lysine had a linear effect on nitrogen intake. However, the relation between SID lysine and nitrogen intake remained constant between the treatments $\left(0.31 \mathrm{~g} \mathrm{~kg}^{-1} \mathrm{BW}^{0,75}\right)$, indicating that the relationship between essential and nonessential aminoacids (EAA:NEAA) in the diets was similar. These results are important because the ratio EAA:NEAA influences the efficiency of nitrogen intake utilization (Heger et al., 2008a).

The amount of nitrogen excreted represented, on average, $47 \%$ of nitrogen intake, of which $35 \%$ was excreted in feces and $65 \%$ in urine (Table 2). These results differ from those obtained by Heger et al. (2008b), who found that only $16 \%$ of nitrogen intake was excreted. However, the proportions in feces and urine were similar to those obtained in the present study: 34 and $66 \%$ in feces and urine, respectively. These differences may be explained

Table 2. Dry matter (DM) intake $\left(\mathrm{g} \mathrm{kg}^{-1} \mathrm{BW}^{0.75}\right)$, metabolizable energy (ME) intake ( $\mathrm{kcal} \mathrm{kg}^{-1} \mathrm{BW}^{0.75}$ ), and nitrogen balance $\left(\mathrm{g} \mathrm{kg}^{-1} \mathrm{BW}^{0.75}\right)$ of pigs fed diets with increasing levels of lysine (values expressed per day).

\begin{tabular}{|c|c|c|c|c|c|c|}
\hline \multirow[t]{2}{*}{ Parameter } & \multicolumn{6}{|c|}{ Levels of lysine ( $\%$ of requirement) StandardProbabi- } \\
\hline & 30 & 50 & 60 & 70 & error & lity ${ }^{(1)}$ \\
\hline Observations & 6 & 6 & 6 & 6 & - & - \\
\hline Average weight (kg) & 51.16 & 51.85 & 52.00 & 52.56 & 0.40 & ns \\
\hline ME intake & 376.2 & 374.5 & 372.9 & 370.9 & 1.11 & ns \\
\hline DM intake & 97.24 & 97.21 & 96.81 & 96.75 & 0.29 & ns \\
\hline Nitrogen ingested & 1.01 & 1.37 & 1.71 & 2.06 & 0.01 & 0.01 \\
\hline Fecal nitrogen & 0.18 & 0.24 & 0.25 & 0.30 & 0.03 & ns \\
\hline Urinary nitrogen & 0.35 & 0.39 & 0.50 & 0.60 & 0.04 & 0.01 \\
\hline Nitrogen excreted & 0.53 & 0.63 & 0.75 & 0.90 & 0.03 & 0.03 \\
\hline Nitrogen absorbed & 0.83 & 1.13 & 1.47 & 1.76 & 0.03 & 0.00 \\
\hline Nitrogen retained & 0.48 & 0.74 & 0.96 & 1.16 & 0.03 & 0.00 \\
\hline Protein deposition & 3.02 & 4.65 & 6.03 & 7.27 & 0.22 & 0.00 \\
\hline
\end{tabular}

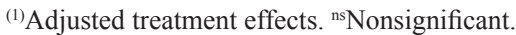

Pesq. agropec. bras., Brasília, v.48, n.9, p.1269-1274, set. 2013 DOI: 10.1590/S0100-204X2013000900011 
by the experimental diets used. In the present study, most of the nitrogen intake was derived from corn and soybean meal. However, Heger et al. (2008b) used purified diets, in which the whole nitrogen was in the form of synthetic amino acids, considered $100 \%$ digestible. The use of purified diets also reduces endogenous losses, decreasing nitrogen loss in animals (Stein et al., 2007).

The linear effect of lysine intake on nitrogen retention shows that the efficiency of amino acid utilization for protein deposition was constant within the evaluated limits. Heger et al. (2008b) observed linear efficiency when lysine supplied $98 \%$ of the requirements for maximum protein deposition. In this experiment, the diet with a higher amount of lysine provided $70 \%$ of the calculated requirements for SID lysine, in order to ensure that the efficiency could be calculated within the limits in which the response was linear.

The relationship between retained lysine utilization and ingested SID lysine (Figure 1) was described by the equation: $\mathrm{y}=-0.0364+0.900 \mathrm{x}, \mathrm{g} \mathrm{kg}^{-1} \mathrm{BW}^{0.75}$ per day $\left(\mathrm{R}^{2}=0.97\right)$, indicating that the daily basal endogenous losses of lysine totaled $36.4 \mathrm{mg} \mathrm{kg}^{-1} \mathrm{BW}^{0.75}$. These results show the need for daily intake of $40.4 \mathrm{mg} \mathrm{kg}^{-1}$ $\mathrm{BW}^{0,75}$ of SID lysine to reach lysine balance, and they represent the estimated maintenance requirement of lysine. This result is similar to that reported by Roth et al. (2003), of $38 \mathrm{mg} \mathrm{kg}^{-1} \mathrm{BW}^{0.75}$. However, Riegel \& Susenbeth (2009) obtained an estimate

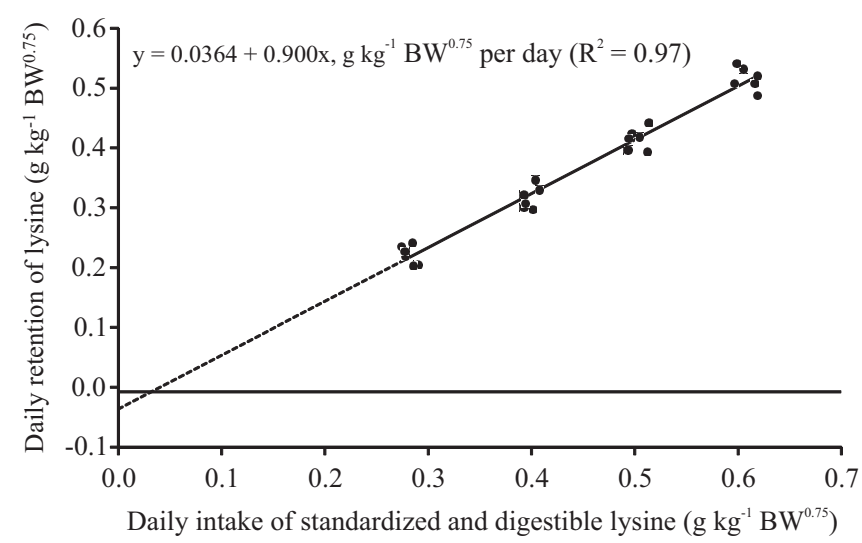

Figure 1. Retention of lysine (y) as a function of the standardized ileal digestible lysine intake $(x)$ in pigs fed with increasing levels of the amino acid.
$60 \%$ higher than the one found in the present study (65 $\mathrm{mg} \mathrm{kg}^{-1} \mathrm{BW}^{0.75}$ ).

The maintenance requirement of amino acids is mainly determined by basal endogenous losses, protein turnover, hair loss and desquamation (Moughan, 2008). Applying the estimates proposed by Noblet et al. (2002) and Moughan (2008) for these components, the maintenance requirement of the calculated SID lysine would be $56.8 \mathrm{mg} \mathrm{kg}^{-1} \mathrm{BW}^{0.75}$, which is $41 \%$ greater than the one estimated in the present study. In relation to lysine, basal endogenous losses, protein turnover, hair loss and desquamation contributed with 54,38 , and $8 \%$ of the maintenance requirements for pig weighing around $50 \mathrm{~kg}$, respectively.

The angular coefficient of the line between the retention of lysine and standardized lysine intake indicates that the marginal deposition efficiency is $90 \%$ (Figure 1). This means that $10 \%$ of the absorbed lysine was lost during metabolic processes. A high efficiency of lysine utilization was also found by other authors: $89 \%$ by Libao-Mercado et al. (2006) and $91 \%$ by Heger et al. (2008b).

The high efficiency of lysine utilization might be associated with its lower turnover rate compared to other amino acid like methionine (Fatufe et al., 2004). The proportion of lysine provided in relation to the requirements for maximizing protein accretion could also determine its efficiency. Furthermore, lysine is retained with greater efficiency $(95 \%$ vs. $15 \%)$ when the proportion of intake represents 40 or $100 \%$ of the requirements calculated, respectively (Heger et al., 2008b).

The lysine synthesized by the microorganisms found in the gastrointestinal tract may contribute more significantly when the consumption is lower than the demand, resulting in an increase of utilization efficiency (Torrallardona et al., 2003). In the present study, the maximum level of supplied lysine accounted for approximately $70 \%$ of the calculated requirements for maximum protein retention. In these cases, the assumption of the constant efficiency of amino acid retention, normally considered in pig growth simulation models, will become invalid. Moreover, when including experimental levels just below the predicted requirements of the amino acid under study, the efficiency of utilization may be overestimated, reducing its practical applicability. 
It is noteworthy that the estimates of the marginal efficiency of lysine retention recommended in simulation models of growth or nutritional requirements are inferior to those obtained in the present study, i.e., $72 \%$ (Van Milgen et al., 2008) and 75\% (National Research Council, 2012). Several factors might contribute to the differences between these data and the ones found in the present work. Among them are the methodology used ( $\mathrm{N}$ balance vs. comparative slaughter), lysine digestibility, lysine ratio in the body protein, and the lysine contents of the experimental diet.

\section{Conclusion}

The endogenous losses of lysine for pigs weighing, approximately, $50 \mathrm{~kg}$ is $36.4 \mathrm{mg} \mathrm{kg}^{-1} \mathrm{BW}^{0.75}$, and these losses generate a maintenance requirement of $40.4 \mathrm{mg} \mathrm{kg}^{-1} \mathrm{BW}^{0.75}$ and a lysine deposition efficiency of $90 \%$.

\section{Acknowledgments}

To Conselho Nacional de Desenvolvimento Científico e Tecnológico (CNPq), for financial support.

\section{References}

CUNIFF, P. (Ed.). Official methods of analysis of AOAC International. $16^{\text {th }}$ ed. Gaithersburg: AOAC International, 1995. $1141 \mathrm{p}$.

FATUFE, A.A.; TIMMLER, R.; RODEHUTSCORD, M. Response to lysine intake in composition of body weight gain and efficiency of lysine utilization of growing male chickens from two genotypes. Poultry Science, v.83, p.1314-1324, 2004.

GILL, J.L.; MAGEE, W.T. Balanced two-period changeover designs for several treatments. Journal of Animal Science, v.42, p.775-777, 1976.

HEGER, J.; KRÍZOVÁ, L.; SUSTALA, M.; NITRAYOVÁ, S.; PATRÁS, P.; HAMPEL, D. Individual response of growing pigs to sulphur amino acid intake. Journal of Animal Physiology and Animal Nutrition, v.92, p.18-28, 2008a.

HEGER, J.; PATRÁS, P.; NITRAYOVÁ, S.; KARCOL, J.; DOLESOVÁ, P. Lysine maintenance requirement and efficiency of its utilisation in young pigs as estimated by comparative slaughter technique. Archives of Animal Nutrition, v.62, p.182-192, 2008 b. DOI: $10.1080 / 17450390802027510$.

LIBAO-MERCADO, A.J.; LEESON, S.; MARTY, B.J.; LANGE, C.F.M. Efficiency of utilizing ileal digestible lysine and threonine for whole body protein deposition in growing pigs is reduced when dietary casein is replaced by wheat shorts. Journal of Animal Science, v.84, p.1362-1374, 2006.

MCKENZIE, J.; GOLDMAN, R.N. The student edition of minitab for windows manual. Belmont: Addison Wesley Longman, 2010. 3008p.

MOEHN, S.; LEVESQUE, C.L.; BALL, R.O. Protein intake but not feed intake affects dietary energy for finishing pigs. Journal of Animal Physiology and Animal Nutrition, v.97, p.197-204, 2013. DOI: 10.1111/j.1439-0396.2011.01262.x.

MÖHN, S.; GILlIS, A.M.; MOUGHAN, P.J.; LANGE, C.F.M. Influence of dietary lysine and energy intakes on body protein deposition and lysine utilization in the growing pig. Journal of Animal Science, v.78, p.1510-1519, 2000.

MOUGHAN, P.J. Efficiency of amino acid utilization in simple-stomached animals and humans - a modeling approach. In: FRANCE, J.; KEBREAB, E. (Ed.). Mathematical modelling in animal nutrition. Palmerston North: Massey University; London: British Library, 2008. p.241-253. DOI: 10.1079/9781845933548.0241.

MOUGHAN, P.J. Simulating the partitioning of dietary amino acids: new directions. Journal of Animal Science, v.81, p.60-67, 2003.

NOBLET, J.; SÈVE, B.; JONDREVILLE, C. Valeurs nutritives pour les porcs. In: SAUVANT, D.; PEREZ, D.; TRAN, J.M.G. (Ed.). Tables de composition et de valeur nutritive des matières premières destinées aux animaux d'élevage: porcs, volailles, bovins, ovins, caprins, lapins, chevaux, poissons. Versailles: INRA, 2002. p.25-35.

NATIONAL RESEARCH COUNCIL. Nutrient requirements of swine. $10^{\text {th }}$ rev. ed. Washington: NRC, 1998. 189p.

NATIONAL RESEARCH COUNCIL. Nutrient requirements of swine. $11^{\text {th }}$ rev. ed. Washington: NRC, 2012. 400p.

POMAR, C.; HAUSCHILD, L.; ZHANG, G.-H.; POMAR, J.; LOVATTO, P.A. Applying precision feeding techniques in growing-finishing pig operations. Revista Brasileira de Zootecnia, v.38, p.226-237, 2009. DOI: 10.1590/S1516-35982009001300023.

RINGEL, J.; SUSENBETH, A. Lysine requirement for maintenance in growing pigs. Livestock Science, v.120, p.144-150, 2009. DOI: 10.1016/j.livsci.2008.05.005.

ROTH, F.X.; JAHN, B.M.; SCHÖNBERGER, W. Essential amino acid requirements for maintenance in adult sows. In: SOUFFRANT, W.B.; METGES, C.C. (Ed). Progress in research on energy and protein metabolism. Wageningen: Wageningen Academic Publishers, 2003. 717-720.

SAKOMURA, N.K.; ROSTAGNO, H.S. Métodos de pesquisa em nutrição de monogástricos. Jaboticabal: Funep, 2007. 238p.

SAUVANT, D.; PEREZ, J.M.; TRAN, G. Tables of composition and nutritional value of feed materials: pigs, poultry, cattle, sheep, goats, rabbits, horses, fish. Paris: INRA, 2004. 304p. DOI: 10.3920/978-90-8686-668-7.

STEIN, H.H.; SÈVE, B.; FULLER, M.F.; MOUGHAN, P.J.; DE LANGE, C.F.M. Invited review: amino acid bioavailability and digestibility in pig feed ingredients: terminology and application. Journal of Animal Science, v.85, p.172-180, 2007. DOI: 10.2527/ jas.2005-742.

Pesq. agropec. bras., Brasília, v.48, n.9, p.1269-1274, set. 2013 DOI: 10.1590/S0100-204X2013000900011 
TORRALLARDONA, D.; HARRIS, I.C.; FULLER, M.F. Pigs' gastrointestinal microflora provide them with essential amino acids. The Journal of Nutrition, v.133, p.1127-1131, 2003.

VAN MILGEN, J.; VALANCOGNE, A.; DUBOIS, S.; DOURMAD, J.; SÈVE, B.; NOBLET, J. InraPorc: a model and decision support tool for the nutrition of growing pigs. Animal
Feed Science and Technology, v.143, p.387-405, 2008. DOI: 10.1016/j.anifeedsci.2007.05.020.

WECKE, C.; LIEBERT, F. Optimal dietary lysine to threonine ratio in pigs (30-110 kg BW) derived from observed dietary amino acid efficiency. Journal of Animal Physiology and Animal Nutrition, v.94, p.1-9, 2010. DOI: 10.1111/j.1439-0396.2009.00969.x.

Received on January 24, 2013 and accepted on August 30, 2013 